\title{
Globalization, Regional Organizations, and the Facets of Higher Education: Taiwan's Perspectives
}

\author{
Joseph M. Chin, Chih-Min Tang, and Robin J. Chen
}

\begin{abstract}
The aim of the study is to examine the influence of the formation and operation of different regional organizations on the higher education within the region. Based on the regulations or agreements of the matured regional organizations, such as EU, NAFTA, FTAA, and ASEAN +3, the study analyzes the influence of the formation of the organizations on their respective regions, the involvement of the nations in the organizations, the relevant education policies adopted by the organizations, with an extension to the higher educational issues focused by the organizations. The international cooperation within the aforementioned organizations is mostly focused on economic activities; however, the training of high quality manpower, which is closely tied to the economic development, has gradually become one of the key discussions for the new agreements between the organizations in the $21^{\text {st }}$ century. Therefore the study compares the educational systems in the process of global and regional alliances to explain how higher education is influenced by these developmental trends, as well as the relationships among the various factors and the implications for Taiwan.
\end{abstract}

Index Terms-Globalization, regional organizations, higher education.

\section{INTRODUCTION}

Recent studies have shown that the significant influence of globalization on the world's political and economic structures is beyond a doubt. Many researchers worldwide have also proposed their own arguments for the influence of globalization on education [1]-[4]. However, in regard to how education is influenced by politico-economic alliances or agreements with the spreading of globalization, only a few studies have examined the relevant developmental trends and their impact on Taiwan. The scholars believed that after the formation and operation of many regional treaties, there should be studies to explore and analyze the trends and the influence on the educational systems, in order to avoid distortion of globalization discourses. The study of changes in the global political and economic structures and its relationship with the educational trends can be traced to the beginning of the 1990's. Following the collapse of the communist nations in Eastern Europe in the late 1980s, the nature of the international organizations changed from political alliance and competition into regional cooperation and agreements geared toward fostering economic development. The European Union (EU), created by the Maastricht Treaty in 1992, the North American Free Trade

Manuscript received May 16, 2014; revised August 12, 2014

Joseph M. Chin, Chih-Min Tang, and Robin J. Chen are with National Chengchi University, Taiwan (e-mail: mcchin@nccu.edu.tw, robin@nccu.edu.tw).
Agreement (NAFTA), created in 1994 composed of Canada, the US, and Mexico, and the Free Trade Area of the Americas (FTAA), in which the negotiations began in 1994 and agreements were finalized in 2005, were all products of this global mindset. Even the Association of Southeast Asian Nations (ASEAN), which was founded in consideration of the regional military and political security as early as 1967 , has been gradually integrating with the regional major countries since 1980s and transforming into a regional organization focused on economic cooperation, becoming the largest economic cooperation body in Asia. Although the main focus of the aforementioned international cooperation within the regional organizations has been on the economy, nurturing high quality human capital, which is closely related to economic development, has become a key objective of the regional agreements in the $21^{\text {st }}$ century. Of particular importance is the cooperation and training of higher education. The ASEAN was established as early as 1967, however, it was not until 2005, under the recommendation of Malaysia, that a regional economic organization modeled after the EU was proposed to be established in 2015. The participation of the three economic powerhouses, China, Japan, and Korea, will evidently form a powerful economic union [5]. The aforementioned developments indicate that Taiwan, as the hub of East Asia, has inevitably faced structural impacts from the new types of regional organizations, formed by the shifting of the global political and economic unions. Given the current situation and targeting at the formation and operation of the current major regional organizations, this study was aimed to analyze how education service changes in response to the global and regional structural changes and will be beneficial for Taiwan in coping with the future development of ASEAN +3 .

\section{THEORIES ON REGIONAL RELATIONS}

With the Cold War ending in the late 1980s, regional political and military alliances underwent qualitative changes, and many social scientists studying the development of regional relations worldwide began systematically analyzing this trend. The analyses of the political theories, federalism and functionalism, are provided in order to deepen the discourse on the regional political and economic structural analyses. Furthermore, neo-liberalism, which has raised several controversial issues under the influence of globalization, is another essential factor for understand regional integration.

\section{A. Federalism}

A religious revolution sparked the Thirty Year's War (1618-1648) in the $17^{\text {th }}$ century. After the end of the war in 
1648 , the countries involved in the war signed the Treaty of Westphalia, ending the religious conflict and recognizing the sovereignty of nations. Idea of Europe) [6]. The significance of this turning point was that the origins of the future wars became national rather than religious conflicts [7]. Some famous philosophers, including Jean-Jacques Rousseau, Immanuel Kant, and Victor Hugo, proposed that humanity should move beyond the concept of nations and work toward the establishment of a federal political area. The most significant example is the "idea of Europe," which was preached in Europe following World War II and was based on the ideal of super nationalism [6]. Chang [8] suggested that "surrender of sovereignty" and "limitation of the exercise of sovereignty" were the two concepts given a lot of attention in the development and discussion of integration of post-war Europe, and that the emphasis and regard of federalism was developed in this context.

Supporters of federalism believe that different regions of the world should move beyond traditional methods of governmental cooperation and create a new form of operation beyond nations in order to improve efficiency and utilize limited resources. Nuttall [9] analyzed the formation of the EU and pointed out that EU was the manifestation of federalism. This is because the establishment of federalism can be scrutinized based on two important factors: first signing of the treaty, which clearly specifies the relationships between the regional union and the member countries of the union as well as the political processes for regional organizations; second, the foundation of the super-national organizations should be established based on the consensuses of exercising sovereignty independently and pursuing common policies.

Regarding the process of integration, federalists state that integration consists of various aspects, including politics, economics, law, transportation, and education. However, political integration is the top priority, because it can promote integration in the other aspects. As a result, it is necessary to first establish an autonomous, central organization above any of the member countries [10]. In summary, federalism implemented in the regional integration emphasizes surrender of sovereignty and establishment of a binding system agreed upon by all members. The purpose is to make better use of resources and improve efficiency. Under the recognition of preventing wars caused by national conflict, federalism provides a comprehensive theoretical foundation for understanding the current regional integration around the world.

\section{B. Functionalism}

In contrast to federalism, in which political integration is considered to be top priority, functionalism is represented by Mitrany, and developed into neo-functionalism under the theoretical revisions by Haas and Lindberg. It emphasizes the separation of politics and economics, and the prioritization of economic integration over political integration in order to sustain the welfare of nations [11]. As early as the beginning of the post-World War II era, Mitrany [12] proposed that the design of functionalism should focus on promoting economic cooperation based on the premise of mediating economic conflicts and pursuing common interests among nations. The reasoning was that political issues tend to be sensitive and perpetually pursuing political integration would inevitably lead to wars, a danger which could be avoided through economic cooperation. Therefore, functionalism emphasizes the establishment of international organizations based on economic cooperation; since it seems to share a common goal with federalism, Mitrany referred it to "federation in installments"

In the discourse on neo-functionalism by Haas [13], it was again confirmed that economic integration should take priority over political integration; nevertheless, the decisive function of political integration was not ignored. Haas believed that when economic cooperation reaches a certain level, it should work with political integration in order to solve political and economic issues caused by economic integration, or solve some major changes caused by the variations of the objective environment. The goal is to ensure that the political/economic environment does not interfere with economic cooperation. Based on this principle, all political measures and negotiation mechanisms, which are able to maintain economic cooperation, have been gradually established in their respective processes. Neo-functionalism's important perspectives on the political support for the economy include planning the organizational objectives, the scope of operations, the definition of functions, the establishment of power structures, the consensus in the decision-making process, and the external relations.

In regard to regional integration, functionalists overturn the traditional ideas with a focus on power politics, asserting that the purpose of the developments of international relations and regional cooperation is to pursue a substantial interest. Such pursuit of a substantial interest is derived from the idea of "spill over" by Haas [13]. He discovered that the initial calls for political integration in Europe were largely ignored by the social elites until the establishment of the European Coal and Steel Community (ECSC) in 1951, from which the social elites obtained benefits. They quickly turned to support the integration of other aspects in hopes of reproducing the same experience. Haas' logic of integration and expansion is to pursue interests by "spilling over" integration to other aspects, trying to expand the practicality. For Haas, "spill over" is not a consequence that automatically occurs, but rather a conscious process. "Spill over only takes place when a participant becomes aware of one's self-interests and wishes to direct all integration benefits toward a new situation" [13]. Neo-functionalism has played an important role in explaining the trends of details and functional differentiation of regional integration worldwide. Following the arguments of neo-functionalism, the relevant discussion on the organizational trends would be further analyzed later in this study.

\section{Neo-Liberalism}

Recent studies in social science, including politics, economy, culture, and education, have mentioned the profound influence of globalization. The idea of regional integration discussed in this study is a type of regional organizational revolution under the influence of globalization. According to Chen [14], discussing globalization is inseparable from investigating the formation 
and influence of neo-liberalism. Jessop [15] proposed that the spirit of neo-liberalism is a model of market competition with international capital and flows of human resources, and the purpose is to expand economic influence and reduce the awareness of national territory. According to Arnove [16], the results of economic globalization show that Fordism, a mass production on a domestic scale, has been replaced by Toyotism, a "just in time" production method. In other words, industrial manufacturing and economic production are no longer limited by national boundaries; with the developments of telecommunication and communication methods created by unique communities, regional cooperation and exchange among nations have become features of this global era. The well-known examples include Coca-Cola-ization and McDonaldization.

The neo-liberal values under globalization also imply the interactive results of economy and education are caused by the influence of international and regional organizations on education. These organizations include the World Bank, IMF, the United States Agency for International Aid (USAID), Canadian International Development Agency (CIDA), and Japan International Cooperation Agency (JICA). However, the operation of aid provided by these organizations may take on different forms due to local and international developments in the process of globalization.

According to Spring [17], the development of education amidst globalization can be discussed in four main areas: knowledge economy, technological and lifelong learning, global immigration and human resources outflow, and neo-liberalism. Because neo-liberalism is one of the sequential effects of expanding global economic power, it can provide a more comprehensive method to understanding the influence of worldwide regional organizations on the development of human resources and economy. Based on this foundation, this study was aimed to explore the managements and competitive strategies of higher education among regional organizations as well as the full impact on the regional organizations' reasoning about the values of privatization and marketization.

\section{DEVELOPMENT OF REgIONAL ORGANIZATIONS}

The study adopts the EU, NAFTA, and the FTAA as examples to explain the developments. The aspects of analysis on regional organizations are mainly focused on three dimensions: the background of establishment, the decision-making systems and processes, and the formation of educational policies. These dimensions serve as a common element between the different regional organizations and are described below.

\section{A. $E U$}

\section{1) Establishment background}

The EU was founded after World War II as the newest phase in the development of political and economic integration among Western European powers. The EU's predecessor was the European Community (EC), comprised of the European Coal and Steel Community (ECSC), European Economic Community (EEC), and European Atomic Energy Community (Euroatom). In the absence of a unified headquarter, the EU's main organizations are the Commission, the Council, the Court of Justice of the European Communities, and the European Parliament.

Based on the aforementioned theoretical illustration, it is clear that the establishment of the EU was significantly influenced by federalism and functionalism, with a commitment to political and designated economic integration in order to promote intra-regional cooperation. In 1992, the 12 member states of the EC signed the Treaty of European Union, also known as the Masstricht Treaty, in Masstricht, Netherlands; the collapse of the communist countries in Eastern Europe in the 1980s also facilitated the birth of the union. In the following year, a unanimous resolution was passed at a summit held in Copenhagen, Denmark, stating that Eastern European countries, which had abandoned communism, were allowed to apply for EU membership on condition that they could fulfill the political and economic conditions established at the summit. By 2010, a total of 27 member states had joined the EU, and had become an independent legal representative, the EU, in the World Trade Organization (WTO) [18].

\section{2) Decision-making systems and processes}

According to the regulations, the power of the EU is exercised through four major organizations: the Council, the Commission, European Parliament, and the Court of Justice of the European Communities. Personnel matters and important decisions are made in accordance with the results of political negotiations between member states. The Council is the EU's highest authoritative organization and is responsible for enacting important policies, the resolution of bills, signing of treaties, and budget reviews. In addition, the Council serves as a place for the representatives of the member states to express their opinions as well as to compete for interests. The Commission is the EU's highest administrative organization, responsible for policy planning, proposal submission, policy coordination among member states, and implementation of common policies. As for the important personnel matters of the Commission, the candidates and the numbers should be agreed upon by the member states and should be appointed according to the corresponding proportions of the member states or rotated.

The Court of Justice of the European Communities is responsible for interpreting treaties and legal acts as well as mediating internal conflicts within the EU. Its functions include pushing the mutually recognized principles forward among the member states, and these ordinary legal principles provide an integrative opportunity for the European legal systems. The coordination between the common law system and the civil law system has stimulated the reforms and developments of the European legal systems. The main functions of the European Parliament include legislative power, partial budgetary power, executing policy recommendations that can influence the Council and Commission and impeaching the inappropriateness of administrative operation by the Commission. Its role has become similar to that of a parliament or a congress of an individual country [19].

\section{3) Formation of education-related policies}

During the economic reconstruction after World War II, 
the common interests of the EC members were to pursue international cooperation and economic recovery, not educational development. It was not until the political and economic depression globally in the 1970s that the member states gradually began awareness of the factors in economic development, such as human resources, technology, and resource development. Among these, the needs of human resources are naturally associated with the implementation of education, and as a consequence, the member states had gradually focused on the methods of training appropriate human capital on the basis of knowledge in order to facilitate economic growth. In 1988, during the EC era, the ministers of education passed a resolution to raise educational quality and in 1993, after the EU was founded, the earlier commitment was reemphasized [20]: Increase the EU

1) identity among the youth, develop a full understanding of European cultures and the fundamental values dedicated by the EU, which are democracy, social justice, and human rights.

2) Encourage the EU citizens to devote to European economic and social developments, and work toward a single EU goal set by the European laws.

3) Educate the European citizens about the potential economic and social advantages brought by the EU, as well as future challenges and coping strategies.

4) Enhance the mutual understanding of the histories, cultures, economy, and societies of all the member states, and further experience the meaning of cooperation between the EU and countries in other regions.

Pepin [20] pointed out that the EU's current educational efforts are directed toward realizing the ideal of higher education within the region. A higher educational region represents that the getting a diploma or taking courses are no longer limited to a single country; rather, the academic credits can be transferred among member states, and even the learning content is compatible and interchangeable across borders. In order to increase the mobility of higher education, the Erasmus Project was founded in 1987 during the EC era, and higher education grants were provided for studying abroad, in hopes that students would understand more about other cultures and values in differ part of Europe, to provide the opportunities of knowledge and student interaction among all member states. Since the Erasmus Project was a success, the Erasmus Mundus Project was further founded in 2004 to extend this experience to students from the non-EU countries. Allowing non-EU students to earn degrees in Europe not only attracts more outstanding students but also builds a global learning center in Europe.

\section{B. NAFTA}

\section{1) Establishment background}

The origin of the NAFTA can be traced back to the Canada-United States Free Trade Agreement in 1988. In 1992 Mexico joined and signed the NAFTA, which went into effect in 1994 and has been continuously functioning to the present day [21]. It is currently the world's largest economic cooperation body in terms of its covered area. After the regional economics have become the focus of global development, and even though Mexico's economic development was far behind the U.S. and Canada, it gained the approval from the U.S. and Canada. The establishment background of the NAFTA is worth investigating.

After the end of World War II, the U.S. relied on its super power and launched the containment policy to stop the global expansion of the former Soviet Union. However, with the decline of the U.S. power, many nations have turned more protective toward domestic industries due to economic reasons, and the ideal of global free trade has come to a stall [22]. In order to protect its interests, the U.S. began to search for solutions, unilateral economic sanctions on one hand and regional trade negotiations on the other. The former was the well-known Section 301 of the U.S. Trade Act with a highly protectionist economic meaning, and the latter was the key point of the current discussion, the establishment of NAFTA. At the same time, the establishment of the EU became a threat to the U.S. in future international trade and economy. To respond effectively, the U.S. allied with Canada and Mexico to form NAFTA and used it as a foundation to expand integration to other countries in Central and South America.

\section{2) Decision-making systems and processes}

NAFTA's main organization is the Free Trade Commission, which is responsible for coordinating and supervising the work of various NAFTA's committees. A secretariat is installed in each member nation to assist the duties assigned by the Free Trade Commission. Furthermore, NAFTA has set up several business committees and working groups, made up of expert representatives from the member nations. There are a small number of advisory committee members, including public and private volunteer representatives. The NAFTA Secretariat also handles disagreements between the committees and working groups [23].

Since NAFTA includes developed nations, such as the U.S. and Canada, and a developing nation, Mexico, its greatest feature is the ability to integrate the advantages of different nations and conduct trade reciprocity through collective bargaining and operation. For example, the U.S. possesses the largest amount of capital and most advanced technology, Canada produces huge amounts of natural resources, and Mexico has an abundant supply of cheap labor that supports production of numerous goods. Although the member nations removed tariff and non-tariff trade barriers within the free trade area, they still maintain their own tariffs and trade policies toward nations outside the area.

\section{3) Formation of education policies}

Education-related issues have not been an important subject throughout the official NAFTA documents and educational measures have been absent from the declarations of the committees, the working groups, and even the organization itself. However, studies on the NAFTA's influence on the region have shown that policies of economic liberalization have indirectly impacted education. For example, Davidson-Harden \& Majhanovich [24] indicated that free trade without tariff barriers brings more education service companies into the education business at various levels, leading to an increase in education privatization. Chiang [25] examined the changes in globalization of higher education and suggested that NAFTA, led by the US, had established professional diploma and certification standards 
for education in order to integrate the human resources market in the region.

Since public educational expenditures have been reduced globally, under the circumstances of less and less overall resources, the free trade agreements imply that education services are becoming commercialized and moving toward free trade. This is especially common in higher education. Barrgan [26] believed that considering the standpoint of economic integration, the focus of higher education revolution is on the technological breakthroughs and the improvements of human resources, which coincides with the characteristic of free enterprise competition. NAFTA's main influence on education is closely related to this.

\section{FTAA}

\section{1) Establishment background}

At the end of 1994, the $1^{\text {st }}$ Summit Americas was held in Miami, U.S.A. All 34 leaders of American nations, excluding Cuba, signed an agreement to establish a free trade block, and agreed to finalize the FTAA negotiations by 2005. The agreement included the following commitments: 1). Finalize a balanced and comprehensive agreement and open up the market to a largest extent under strict regulations; 2). Achieve concrete progress by $2000 ; 3$ ). Ensure and improve labor rights; 4). Support trade liberalization and environmental protection policies [27]. The greatest advantage of this agreement was to unite Central and Latin America with the original NAFTA nations in North America, creating the world's largest regional economic cooperation organization. The symbolic importance cannot be undermined and ignored. Prior to the establishment of the FTAA, the Americas already had several cross national economic organizations, including NAFTA, the Southern Cone Common Market, the Caribbean Community and Common Market, and the Andean Community. So while the FTAA refers to a new free trade agreement nominally, it is in fact an integration of the existing regional organizations, and the original regional or bilateral agreements continuously operate in the spirit of the FTAA [28].

\section{2) Decision-making systems and processes}

The operation of the FTAA is mainly comprised of administrative affairs agreed upon by the 34 national leaders at the summit. The core of decision-making process is supported by the Ministerial Meetings of trade ministers, the Americas Business Forum of private business leaders, and the Trade Negotiations Committee of vice trade ministers, in charge of 9 negotiation groups responsible for different issues. The Americas Business Forum was the first private organization that was allowed to participate in a regional economic cooperation organization and it has tremendous symbolic significance. The summit of 34 national leaders, periodically convened, has had a total of 5 meeting to date. At the end of each summit, official reports on the influences and relevant measures of consensuses will be made by member nations and multiple exchanges will be engaged [29]. That being said, consensuses are not always reached, as it can be difficult for the small number of developed nations and large number developing nations to agree on the sensitive issues, such as agriculture, labor, and the environment [30].

\section{3) Formation of education policies}

According to the evaluation report by Inter-American Development Bank [31] on economic and social progress in the free trade block, the overall illiteracy rate should be decreased substantially due to economic cooperation, and continued efforts are needed in gender equality and in increasing the enrollment rate in basic education. Because the Inter-American Development Bank is part of the FTAA, it had proposed several approaches to the FTAA, such as reducing illiteracy, gender equality, and increasing school enrollment rate, and the majority of the member nations have followed the suggestions as directions for improvement. Low enrollment rate and poverty have long been a vicious cycle, therefore improving the enrollment rate and quality through the demand for economic development will contribute to the further developments of the region's economic and trade agreements.

The Inter-American Development Bank [31] formulated an education policy for the national leaders, which included three recommendations: educational design must be able to respond to the changes in the current situation and demand; education must be able to fulfill the needs of different age groups; and education services must assist public and private resources to reach the maximum efficiency. According to this spirit, the importance of private resources or parent participation in the education system is emphasized; in comparison with the previous centralized system, this report points out the importance of school autonomy in operation.

\section{ASEAN + 3}

After World War II, many Southeast Asian countries, previously relying on the Western powers for the security and independence, had come to the realization that with the rise of national consciousness, how national identity and regional identity should be established amidst a globally competitive environment. Awakened by the sense of national consciousness, these nations began to realize that historical interference by foreign powers did not bring benefits to the region, and thus, a framework for multilateral cooperation was gradually created, which eventually turned into the ASEAN+3.

\section{A. Establishment and Development of the ASEAN + 3}

The ASEAN was founded in 1967 in Bangkok, and included five member nations: Indonesia, Malaysia, Singapore, Thailand, and the Philippines. Nevertheless, the ASEAN was not the region's first international organization; as early as 1954, the Southeast Asia Treaty Organization (SEATO) was founded under the direction of the U.S. The ASEAN was neither the first organization founded in Southeast Asia; the Association of Southeast Asia (ASA), established in 1961, and the Maphilindo, established in 1963, were both founded by the nations in the region. Unfortunately, the SEATO, Maphilindo, and ASA had gradually fallen and eventually terminated, and only the ASEAN continued to develop, expanding into the ASEAN + 3 with the join of China, Japan, and Korea [32].

Unlike the EU, the ASEAN + 3 is not run by systematized and compulsory regulations. This is because over the last 
century, there have been territory conflicts in Indonesia, Malaysia, Thailand, and the Philippines, and none of them are willing to discuss or resolve these issues in a multilateral framework in fear of the enforced intervention from the other nations through the means of majority of votes [14]. In fact, no country is willing to sacrifice its interest for the sake of regional cooperation. The differences between this organization and NAFTA and the FTAA, however, include the absence of a regional leading power, such as the U.S.; in addition, some nations still maintain close relations with foreign powers outside the region.

The aforementioned analysis shows that the nations of ASEAN +3 still guard against the invasion of sovereignty. It is suggested that the "ASEAN model" has recently become a popular term quoted in Southeast Asian studies. While a single definition of the ASEAN model has not yet been agreed upon, a consensus has been reached on several principles of the operation of the ASEAN +3: negotiation talks, adoption of consensus decision-making, non-interference, and opposition to the use of force. With the guidance of these principles on the operational structure of the ASEAN +3, the charter states that the semiannual summits represent the highest policy-making institution, which is in charge of the Secretariat supervising regular affairs, the Coordinating Council and the Community Council coordinating daily affairs of the nations. In addition, specific ministerial meetings are held for implementation issues. Most of the members are heads of departments from various nations, and therefore most of the discussion is principle-based. Once the consensus is made, implementation details are passed down to the secretariats of each nation [33].

\section{B. ASEAN +3 Educational Exchange and Agreements}

The Charter of the ASEAN [32] states that the purpose of the organization is to promote cooperation in politics, security, economy, and social culture. Most educational measures are developed and discussed in the ASEAN Education Ministers Meetings under the guidance of Charter. At the 2005 Summit, members agreed to regularly hold education minister meetings in order to strengthen the regional educational cooperation and consensuses. In regard to specific measures, the Education Ministers Meeting also listed four areas of priority: 1). Increase the ASEAN awareness among citizens, especially the young people, in the region; 2). Enhance recognition of the ASEAN through education; 3). Establish human resources in education; 4). Expand the regional networks of universities in ASEAN. In addition to the Education Ministers Meetings, a standing ASEAN Subcommittee on Education (ASCOE) was established to discuss other principal educational issues.

In fact, as early as 1965 the regional ministers had already established the Southeast Asian Ministers of Education Organization (SEAMEO) in order to develop human resources in the region. However, the education ministers decided to combine the functions of the ASEAN and SEAMEO; that is, the educational priorities listed by the ASEAN should be implemented through the cooperation with SEAMEO. The annual Education Ministers Meetings, a decision made by the leaders in 2005 Summit, have been convened for four times, and after the end of each meeting, a joint statement is issued [34]-[36]. In regard to the implementation of education, all ASEAN educational cooperation programs/activities are passed in the annual Education Ministers Meetings, and are carried out by the ASEAN Senior Officials on Education (referred to SOM-ED in the study), who report directly to the Education Ministers Meetings. SOM-ED also supervises higher education cooperation, which is directed by the ASEAN University Network (referred to AUN in the study).

\section{ASEAN +3 Education Development and Trends}

It is clear that the educational interaction and exchange in the ASEAN +3 are primarily focused on higher education and the operation is managed mainly by the AUN. There are four main aspects: 1 . Improve cooperation among regional scholars and experts; 2. Develop regional academic and occupational human resources; 3. Increase information exchange among regional academic groups; 4. Improve regional identity and create a sense of ASEAN-ness through education [37].

Participation in the AUN is currently limited to 21 universities in 10 nations of the ASEAN. The number does not include the three countries, China, Japan, and Korea, that joined ASEAN later. The AUN is composed of the Board of Trustees (BOT), 21 participating universities, and 3 secretariats. The Board of Trustees includes all ASEAN member representatives, the ASEAN secretary-general and the chairman of the educational team committee, and the CEO of AUN. Important higher education policies are still made by the AUN's Board of Trustees. When the AUN was founded in 1995, it only had 13 universities from 7 member nations, and daily affairs were managed by the secretariat, which was located at Chulalongkorn University in Bangkok, Thailand.

The study by Gajaseni [38] on the operation of AUN indicated that one of its special characteristics was the development of dialogue partner relationships with universities outside the region, including those in Australia, Canada, China, the EU, India, New Zealand, Russia, and the U.S. Like the AUN universities, dialogue partners can submit proposals or programs, and can carry them out once they are approved by the AUN's Board of Trustees. The original focuses of AUN were on the exchange visits by the university teachers and students in the region, research topics on Southeast Asia, and research projects on cooperation. Recently, the focus has been shifted to quality assurance for universities. For the AUN, quality assurance provides a right direction for teaching, research, and regional cooperation. How to improve the regional research quality depends on the successful implementation of a quality assurance mechanism. In order to achieve quality assurance, the AUN secretariat in Chulalongkorn University post an announcement in 2000, asking that all universities participating in the AUN should appoint a Chief Quality Officer (CQO). CQO meetings are scheduled twice a year, and are alternately hosted by the participating universities, with a focus on establishing standards for university quality.

\section{CONCLUSION}

Limited by the current international situation, Taiwan is 
not able to participate in the regional political and economic organizations. Nonetheless, in order to respond quickly to global competition Taiwan cannot isolate itself from the agreements and regulations of these regional organizations. For the purpose of expediency, Taiwan should familiarize itself with the developmental directions of policies and agreements in order to develop effective regional competitive strategies for the future. Based on the analyses above as well as the developmental directions of the current organizations, several feasible solutions were proposed for Taiwan's future.

\section{A. Connect with International Standards of Quality Assurance in Higher Education}

The EU, which has an excellent operating system, has declared to work on the education systems at all comprehensive levels. However, its objective of creating a European higher education zone requires an educational environment without borders, and the premise of "without borders" is to ensure the homogeneity of education quality among the members. The strong influence of globalization implies that enhancing the quality of talents should be achieved through the educational requirements in the regional economic organizations. For that reason, establishing a higher education environment, similar to EU, with equal quality standards will reduce the impact in education caused by the current situation in which Taiwan is not represented in international organizations.

Additionally, one of the major annual works of AUN includes the educational quality assurance meetings. Judging from the fact that the participating universities in ASEAN are at the top rank of their nations, and several universities have introduced their standards of quality assurance to their respective nations. In regard to quality assurance, if Taiwan is able to conform to the standards of international organizations, it will accomplish great achievements in training high quality human capital.

\section{B. Apply to Politically-Neutral Secondary Regional Organizations}

In the example of the AUN's network, the partners are general universities, and are not limited to those in the member nations of the ASEAN +3. As a consequence, universities in the U.S., Russia, and India participate in the network. It is beneficial for Taiwan to consider a similar operation. On one hand, there will be no political disputes involved. On the other hand, it can concentrate on playing a professional role. By participating in secondary organizations, Taiwan will be able to indirectly exchange experience with other regional members and absorb new international knowledge.

The institutes of higher education in Taiwan already have established their own cooperative systems with foreign institutes and schools, however, most of them are limited to bilateral exchange and visits. If Taiwan could strategically select appropriate universities or institutions and establish cooperative relations with universities in the AUN network, through regular and systematic exchange, Taiwan can indirectly participate in the AUN and thereby offset the disadvantage of being absent from the education agreements of ASEAN +3.

\section{Establish Bilateral Agreements and Exchange with the Individual Major Nations of the Asean +3}

The spirit of the ASEAN +3 agreements emphasizes avoiding the interference of the regional power in bilateral exchange or visits between any nations. Given this condition, Taiwan may take advantage of such principle to conduct bilateral exchange with countries of friendship and further establish ASEAN-style agreements on appropriate educational issues in order to avoid marginalization of regional higher educational exchange.

While establishing relations with major nations of the ASEAN +3, Taiwan should raise the decision-making level of educational exchange by setting up advisory committees at the national level, rather than at the level of specific universities or institutions. In the establishment of bilateral agreements, Taiwan should take into consideration the future possibility of connecting with the ASEAN +3 , and maintaining flexibility.

\section{Establish an ASEAN +3 Educational Issue Response Center}

Since 2005, the ASEAN+3 has convened annual education ministers meetings and issued joint statements after the meetings in order to establish tradition. However, Taiwan has not yet faced the positive influence of this mechanism. Analyzing the ASEAN +3 only in the academic research realm will have very limited effects on the globalization of education. A more appropriate approach is to analyze the joint statements of the annual education ministers meetings and apply the results to policy making.

Another concrete approach involves the establishment of an ASEAN +3 educational issue response center at the central level. The response center is responsible for regularly performing research and coordination with the educational agreements and declarations issued by ASEAN +3 . As other nations have established response mechanisms for ASEAN +3 , Taiwan can establish similar mechanisms in education, laying down the foundation of future directions for participating in regional organizations.

\section{REFERENCE}

[1] C.-T. Wu, An Analysis of Educational Policy: Concepts, Methods, and Application, Taipei City: Advanced, 2008.

[2] S.-R. Chan, "Economic crisis and education development: impact and response strategies," in Y.-M. Su and Y.-C. Fang ed., Facing Future Educational Challenges, Taipei City: Hsueh-Fu, pp. 13-38, 2009.

[3] C.-Y. Chou, Comparing Educational and International Educational Reform, Taipei City: Sanmin, 2009.

[4] G. Hamilton and R. Freenstra, "The organization of economics," in M Briton and V. Nee Ed., The New Institutionism in Sociology, Stanford, CA: Stanford University Press, pp. 153-180, 2001.

[5] ASEAN. (2009). Cebu Declaration on the Acceleration of the Establishment of an ASEAN Community by 2015. [Online]. Available: http://www.aseansec.org/19260.htm

[6] W. Lipgens, "The triumph of the supernational principle in the resistance," A History of European Integration, vol. 1, pp. 44-57, 1982.

[7] D. Heaterm, The Idea of European Unity, Leicester, UK: Leicester University Press, 1992.

[8] Y.-C. Chang, European Unification: Interaction between Intergovernmentalism and Supranationalism, Taipei City: Yang-Chih, 1998.

[9] S. J. Nuttall, European Political Cooperation, Oxford, UK: Clarendon Press, 1992.

[10] R. J. Harrison, Europe in Question: Theory of Regional Integration, New York: New York University Press, 1974. 
[11] T.-C. Hung, "Theory and practice of the European Union," H.-C. Shen and T.-C. Hung ed., The European Union: Theory and Policy, Taipei City, Taiwan: Institute of European and American Studies, Academia Sinica, 1998

[12] D. Mitrany, A Working Peace System: An Argument for the Functional Development of International Organization, London, UK: Royal Institute of International Affairs, 1946.

[13] E. B. Haas, Beyond the Nation State: Functionalism and International Organization, Stanford, CA: Standord University Press, 1964.

[14] R. J. Chen, "The state, new labour, and the changes in education," The Associateship Dissertation, Institute of Education, University of London, 2008.

[15] B. Jessop, The Future of Capitalist State, London, UK: Polity Press, 2002.

[16] F. Arnove, "Reframing comparative education: the dialectic of the global and the local," in F. Robert and F. Arnove ed., Comparative Education: the Dialectic of the Global and the Local, Maryland: Rowman \& Littlefield Publishers, 1999.

[17] J. Spring, "Research on globalization and education," Review of Educational Research, vol. 78, no. 2, pp. 330-363, 2008.

[18] EU. (2010). Why the European Union? [Online]. Available: http://europa.eu/abc/12lessons/lesson_1/index_en.htm

[19] EU. (2010). EU institutions and other bodies. [Online]. Available: http://europa.eu/institutions/index_en.htm

[20] L. Pepin, "The history of EU cooperation in education and training," European Journal of Education, vol. 42, no. 1, pp. 121-132, 2007.

[21] NAFTA. (2008). 2008 Annual Report. [Online]. Available: http://www.nafta-sec-alena.org/en/view.aspx? $\mathrm{x}=202$

[22] K. Roberts and M. Wilson, Policy Choices: Free Trade among NAFTA Nations, East Lansing, Michigan: Michigan State University Press, 1996.

[23] NAFTA. (1994). NAFTA Organization. [Online]. Available: http://ustr.gov/regions/whemisphere/organizations.shtml

[24] A. Davidson-Harden and S. Majhanovich, "Privatisation of education in Canada: A survey of trends," International Review of Education, vol. 50, no. 3, pp. 263-287, 2004.

[25] L.-C. Chiang, "An exploration of course topics of internationalized higher education curricula in a global age," Researching Information, vol. 25 , no. 6 , pp. 11-20, 2008.

[26] J. Barrgan, "The global education and the north American Free Trade Agreement (NAFTA): Exploring the opportunities for international education," International Journal for Good Conscience, vol. 2, no. 2 pp. 26-32, 2007.

[27] FTAA. (1994). The FTAA: A Commitment to Fair and Open Trade. [Online]. Available: http://usinfo.state.gov/journals

[28] Inter-American Development Bank. (1999). IDB 1999 Annual Report. [Online]. Available: http://www.iadb.org/exr/ar99/ar99home.htm

[29] Summits of the Americas. (2010). National Reports and Executive Summaries. [Online]. Available: http://www.summit-americas.org/nat_reports.html

[30] Ministry of Economic Affairs. (2004). Free Trade Agreement of the Americas. [Online]. Available: http://cweb.trade.gov.tw/kmi.asp?xdurl=kmif.asp\&cat=CAT517

[31] Inter-American Development Bank. (2000). IDB 2000 Report on Economics and Social Progress. [Online]. Available: http://www.iadb.org/news/search.cfm?type=AN\&lang=en

[32] ASEAN. (2008a). ASEAN Charter. [Online]. Available: http://www.aseansec.org/21829.htm

[33] ASEAN. (2006). Joint State of the $41^{\text {st }}$ SEAMEO Council Conference and the 1st ASEAN Education Ministers Meeting. [Online]. Available: http://www.aseansec.org/18327.htm
[34] ASEAN. (2007). Joint State of the $42^{\text {nd }}$ SEAMEO Council Conference and the $2^{\text {nd }}$ ASEAN Education Ministers Meeting. [Online]. Available: http://www.aseansec.org/20929.htm

[35] ASEAN. (2008). Joint State of the $3^{\text {rd }}$ ASEAN Education Ministers Meeting. [Online]. Available: http://www.aseansec.org/21428.pdf

[36] ASEAN. (2009). Joint State of the $4^{\text {th }}$ ASEAN Education Ministers Meeting. [Online]. Available: http://www.aseansec.org/18327.htm

[37] ASEAN. (2005). ASEAN Cooperation on Education Overview. [Online]. Available: http://www.aseansec.org/21002.htm

[38] N. Gajaseni. (2007). ASEAN Cooperation Initiative in Quality Assurance. [Online]. Available: http://www.hrk.de/de/download/dateien/AUN_QA_Network.pdf

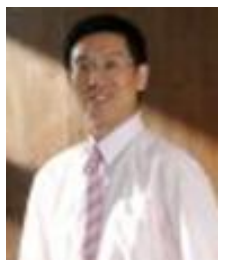

Joseph M. Chin was born in Taipei, Taiwan and received the $\mathrm{PhD}$ degree at University of Wisconsin-Madison in 1985. His major fields of study are educational administration, educational evaluation, and school management.

He was the director of the Department of Education at National Chengchi University from 1997 to 2000; and the dean of the College of Education from 2002 to 2008. At present he is a distinguished professor and the director of the Graduate Institute of Educational Administration and Policy. He has published numerous books and journal papers. His recent books include Educational Administration: Theory \& Practice, Educational Leadership, both which are highly recognized in the field of education administration.

Prof. Chin received the Life Achievement Award for professional research from Educational Administration Society Taiwan (EAST) in 2009.

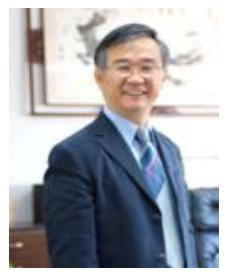

Chih-Min Tang was born in Hualien, Taiwan and received his $\mathrm{PhD}$ degree at National Chengchi University, Taiwan in 1990. The major fields of study are educational administration and policy, school buildings management, and leadership of the principal.

He was the principal of Affiliated High School of National Chengchi University from 1998 to 2009, and was the director of the Department of Education. A present, he is the dean of the College of Education of National Chengch University. He has dozens of influential publications, including School Buildings in Taiwan and School Buildings \& Campus Planning have great impact on the academic community in Taiwan.

Prof. Tang was the president of the Association of Educational Administration, R.O.C. He is now the president of the Association in Research of the School Buildings, R. O.C.

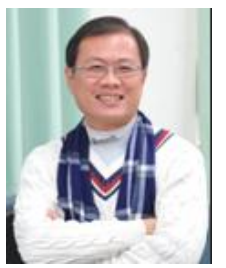

Robin J. Chen was born in Kaohsiung, Taiwan and respectively received the $\mathrm{PhD}$ and associate degrees at National Chinen University, Taiwan and University of London in 2008. The major fields of study are comparative education and sociology of education

$\mathrm{He}$ was the research fellow and the director of National Academy for Educational Research from 2009 to 2013. Currently he is the associate professor affiliated with the Department of Education, National Chengchi University, Taiwan. He has dozens of influential publications both in western and Taiwanese publishers.

Prof. Chen is also the coordinating professor of Seattle Pacific University and a guest professor of Tohoku University, Japan. He serves as the secretary-general of Association of Educational Administration in R. O.C. and the vice president of Association of International and Cross Straight Culture/Education Studies. 